\title{
Ecological Restoration of Wetland Polluted by Heavy Metals in Xiangtan Manganese Mine Area
}

\author{
Yang Lin ${ }^{1, *}$, Yunan Jiao ${ }^{1}$, Meifang Zhao ${ }^{2}$, Guangjun Wang ${ }^{2}$, Deming Wang ${ }^{3}$, Wei Xiao ${ }^{4}$, Huajun Li ${ }^{5}$, Zhuo Xu ${ }^{1}$ \\ and Yuqi Jiang ${ }^{4}$ \\ 1 Bangor College, Central South University of Forestry and Technology, Changsha 410018, China; \\ huatutujyn@163.com (Y.J.); zhx19zrf@bangor.ac.uk (Z.X.) \\ 2 College of Life Science and Technology, Central South University of Forestry and Technology, \\ Changsha 410018, China; T20131447@csuft.edu.cn (M.Z.); wanggi652@163.com (G.W.) \\ 3 Entrepreneurship and Innovation College, Central South University of Forestry and Technology, \\ Changsha 410018, China; T20041291@csuft.edu.cn \\ 4 Forestry College, Central South University of Forestry and Technology, Changsha 410018, China; \\ sawfly_2008@126.com (W.X.); jiang770406@163.com (Y.J.) \\ 5 Transformation of Scientific and Technological Achievements and Technical Service Center, Chinese Academy \\ of Forestry, Changsha 410018, China; lihua88jun@126.com \\ * Correspondence: Yanglin9098@csuft.edu.cn
}

check for

updates

Citation: Lin, Y.; Jiao, Y.; Zhao, M.; Wang, G.; Wang, D.; Xiao, W.; Li, H.; $\mathrm{Xu}, \mathrm{Z}$.; Jiang, Y. Ecological Restoration of Wetland Polluted by Heavy Metals in Xiangtan Manganese Mine Area. Processes 2021, 9, 1702. https:// doi.org/10.3390/pr9101702

Academic Editors: Zhiqiang Sun, Yi Man and Sheng Yang

Received: 5 August 2021

Accepted: 13 September 2021

Published: 23 September 2021

Publisher's Note: MDPI stays neutral with regard to jurisdictional claims in published maps and institutional affiliations.

Copyright: (c) 2021 by the authors. Licensee MDPI, Basel, Switzerland. This article is an open access article distributed under the terms and conditions of the Creative Commons Attribution (CC BY) license (https:// creativecommons.org/licenses/by/ $4.0 /)$.

\begin{abstract}
Due to manganese mining and slag accumulation, the geological structure of the wetland polluted by heavy metals in Xiangtan Manganese Mine area was seriously damaged, hence biodiversity loss, severe soil, and water pollution, as well as serious heavy metal pollution to food, vegetables, and other natural sources. In order to restore the ecological environment of the mining area, in 2015, the ecological restoration test of heavy metal polluted wetlands in the mining area was carried out. The results showed that the Mn content of different parts of Koelreuteria paniculata root from high to low order: fine root $>$ small root $>$ medium root $>$ large root. The Mn content of different parts of Elaeocarpus decipiens root from high to low order: large root $>$ medium root $>$ small root $>$ fine root. The order of Mn content in plants of the wetland restoration from high to low is as follows: Canna warscewiezii $>$ Thalia dealbata $>$ Boehmeria $>$ Pontederia cordata $>$ Typha orientalis $>$ Nerium oleander $>$ Softstem bulrush $>$ Iris germanica $>$ Acorus calamus $>$ Arundo donax $>$ Phragmites australis; The order of Internal $\mathrm{Cu}$ content from high to low is as follows: Acorus calamus $>$ Thalia dealbata $>$ Softstem bulrush $>$ Canna warscewiezii $>$ Typha orientalis $>$ Arundo donax $>$ Boehmeria $>$ Iris germanica $>$ Pontederia cordata $>$ Nerium oleander $>$ Phragmites australis; Zn content from high to low order is as follows: Canna warscewiezii $>$ Acorus calamus $>$ Thalia dealbata $>$ Typha orientalis $>$ Pontederia cordata $>$ Arundo donax $>$ Softstem bulrush $>$ Iris germanica $>$ Boehmeria $>$ Phragmites australis $>$ Nerium oleander; Cd content from high to low order is as follows: Phragmites australis $>$ Softstem bulrush > Thalia dealbata $>$ Nerium oleander $>$ Boehmeria $>$ Canna warscewiezii $>$ Acorus calamus $>$ Iris germanica $>$ Typha orientalis $>$ Pontederia cordata $>$ Arundo donax. The results of this study have provided a theoretical basis and decision-making reference for the evaluation of heavy metals polluted wetland restoration, protection, and reconstruction effects and the selection of ecological restoration modes.
\end{abstract}

Keywords: ecological restoration; wetland habitat; ecological interception system; Xiangtan manganese ore; hyperaccumulator

\section{Introduction}

With the development of industry and the increase in its demand, large-scale minerals are being mined with mechanized operation [1,2]. Especially since modern times, the mining industry has been developing at a faster pace. At present, the development and utilization of mineral resources in China is generally extensive. Mining is often accompanied by varying degrees of impact and damages on the surrounding environment. 
Mining and mine environmental problems coexist, and the contradiction continues to intensify. Due to the emission and diffusion of pollutants into the air, water, soil, plants, and animals, high concentrations of $\mathrm{HMs}$ and metalloids ( $\mathrm{Zn}, \mathrm{Pb}, \mathrm{Cd}, \mathrm{As}, \mathrm{Tl}$, etc.) can be found in and around active and abandoned mines or smelting plants. Mining activities often lead to a serious decline in soil, water, and ecological environmental quality, soil erosion and reduction of agricultural and fishery production, and directly affect the food, drinking water safety, and human health in the area. At the same time, mining will also lead to the loss and fragmentation of local animal and plants' habitats, as well as biodiversity loss; mining activities have greatly changed the structure and function of the local ecosystem, affecting the landscape pattern and safety of the whole area. It has destroyed and occupied a large amount of land resources, intensifying the contradiction between people. Mining process is often accompanied by serious environmental pollution and ecological safety problems. The main problems of the ecological environment in mining areas include excessive heavy metals, lack of soil nutrients, changes in soil physical and chemical properties, and extreme changes in soil acidity [3-5]. These problems pose a serious threat to the native habitat of the ecosystem and the structure and function of plants. They can lead to biodiversity loss and ultimately seriously affect the production and life of residents and to a certain extent affect the ecological security of the entire region [6-8]. Therefore, effective assessment of soil HM contamination is an important global issue [9]. The most serious problems of ecology and environment in the mining area often occur in the slag area in the abandoned mining area. Because the original soil is covered by slag and the surface is composed of slag from different ages, these slags often lack vegetation and are exposed, which can easily produce soil loss and pollute the regional land and wetlands, and thus cause the pollution of drinking water and food and vegetables $[10,11]$. At present, pollution in mining areas has become a global problem, mainly manifested by the large polluted land area, complex pollution composition, and great difficulty to recover. Relevant research pointed out that the environmental problems caused by mining had lasted for a very long time, even for hundreds of years, which would seriously affect the local economic and social development.

In order to restore the damaged and polluted environment in the mining area, a scientific and reasonable evaluation of the contaminated soil must be conducted in the first place to understand the migration law and characteristics of heavy metals and carry out targeted ecological restoration. It is very important to select appropriate evaluation methods and indicators. At present, mature evaluation indicators for the geochemical assessment of the soil environment include contamination factor $\left(C_{\mathrm{f}}\right)$, degree of contamination $\left(\mathrm{C}_{\mathrm{deg}}\right)$, pollution load index (PLI), and geo-accumulation index $\left(\mathrm{I}_{\text {geo }}\right)$. These indicators enable the estimation of environmental risk and soil degradation due to accumulation of HMs [12-15]. In the study of heavy metals migration, isotope analysis proved to be a promising tool, helping us to understand heavy metals behavior by the smelting process and in plant tissue study $[16,17]$.

In the selection of ecological restoration methods, the United States developed the permeable reaction wall technology for treating polluted water in the 1980s, which was very representative. As of now, a large number of engineering and technical studies on this technology have been conducted in Europe and the United States and other countries, and this technology has gradually entered the stage of commercial application. Permeable reaction wall technology is an in situ treatment method for groundwater pollution. It has two kinds of process flows: continuous wall, water separation funnel, and water diversion gate, but the principle is the same. The treatment system consists of an inlet tank, a reaction zone, and an outlet tank. Active material walls are arranged in the system to intercept the contaminated plume. After the contaminated plume reacts with the medium filler through the reaction zone, the pollutants are transformed into another form acceptable to the environment, so as to achieve the purpose of reaching the treatment standard. The reaction medium is usually strong in chemical reduction, which can remove chromium, uranium, selenium, cobalt, copper, mercury, arsenic, and other heavy metal elements, as 
well as nitrate and sulfate. In the redox reaction, heavy metals are precipitated as simple substances or insoluble compounds.

In recent years, the ecological interception system based on permeable reaction wall technology is mainly used to control agricultural non-point source pollution and protect the water ecological environment of the basin. The types of ecological interception system vary from place to place, including plant buffer zone, ecological ditch composed of agricultural drainage ditch and its internal plants, and multi-level ecological interception zone constructed by different tree species on different platforms. Its action mechanism is to intercept runoff and sediment by constructing the system and use the system plants to absorb and remove other non-point source pollutants.

The surface soil of Xiangtan Manganese mining area is formed by the accumulation of slag in different years, and others heavy metals associated with Mn occur commonly in slag produced by manganese processing. The complex processing of Mn-bearing ores probably dominates in areas where extreme pollution levels of this element have been recorded [16]. According to relevant research, we believe that the HM content in the topsoil formed in Xiangtan Manganese mining area is mainly related to the natural existence of metals [9,16-18]. The contaminated soil in Xiangtan Manganese mining area is not only the receptor of pollutants such as mining wastewater and waste residue but also a source of pollution in the surrounding area. Soil leakage and surface runoff caused by rainfall, especially soil and water loss during rainstorm, will lead to the diffusion of pollution and harm the soil and water ecological environment around the mining area. The soluble metal ions and compounds in contaminated soil will eventually enter the water body, which will affect the safety of diet and drinking water in a larger area, although the pollution decreases with the distance from the slag, which is consistent with V. Chrastný research [18]. It usually takes a long time to use bioremediation technology to repair heavy metal contaminated soil. Therefore, before realizing the long-term goal of ecological restoration in polluted areas, it is necessary to take appropriate measures to establish soil leakage and surface runoff interception and treatment system to control the diffusion of heavy metal pollution, so as to ensure the ecological safety of the surrounding environment of the mining area.

\section{Research Methods}

\subsection{Overview of the Study Area}

Xiangtan Manganese Mine Area is located $14 \mathrm{~km}$ northwest of Xiangtan, Hunan Province, China, at $112^{\circ} 45^{\prime} \sim 112^{\circ} 55^{\prime}$ (55' E and $27^{\circ} 53^{\prime} \sim 28^{\circ} 03^{\prime}$ N) $[19,20]$. Xiangtan Manganese Mine area has a typical subtropical monsoon climate with obvious characteristics: obvious seasonal changes in precipitation and temperature and an average annual precipitation of $1425 \mathrm{~mm}$ [21,22]. Summer is hot and drier, winter is cold and humid, the highest temperature is $41.8^{\circ} \mathrm{C}$, the lowest temperature is $-12.1{ }^{\circ} \mathrm{C}$, and the annual average temperature is $17.5^{\circ} \mathrm{C}$ [23]. Northwest winds prevail in winter and southeast winds prevail in summer. The summer drought lasts for an average of 30-40 days, with an average relative humidity of $80 \%$ and an average frost-free period of 300 days. After nearly a hundred years of mining, Xiangtan mineral resources are exhausted, leaving a fragile geological structure and serious environmental pollution [24]. In 2011, the government decided to remediate the local geological damages and solve the ecological problems in Hunan-manganese region (Shown in Figure 1).

The wetland is located in the manganese ore mining area, with serious heavy metal pollution, which mainly comes from the mining wastewater and waste residue in the original mining area, and it is also a pollution source in the surrounding area. Wastewater and waste residue can be spread through surface runoff and soil erosion under natural circumstances, bringing great potential dangers to the ecological environment of the wetlands and the surrounding areas. The water quality of the two wetlands was acidic, with the average $\mathrm{pH}$ value of 5.2. The heavy metal content in the water is extremely high, with an average Mn content of $28.05 \mathrm{mg} / \mathrm{L}$. The main problems facing the restoration project are: (1) the water quality is perennial acidic; (2) heavy metal pollution; (3) Serious soil erosion; 
(4) The geological structure is unstable; (5) surrounding wetland is mainly slag without soil; (6) the slag mountain color is black, and the highest temperature in summer is $68^{\circ} \mathrm{C}$.
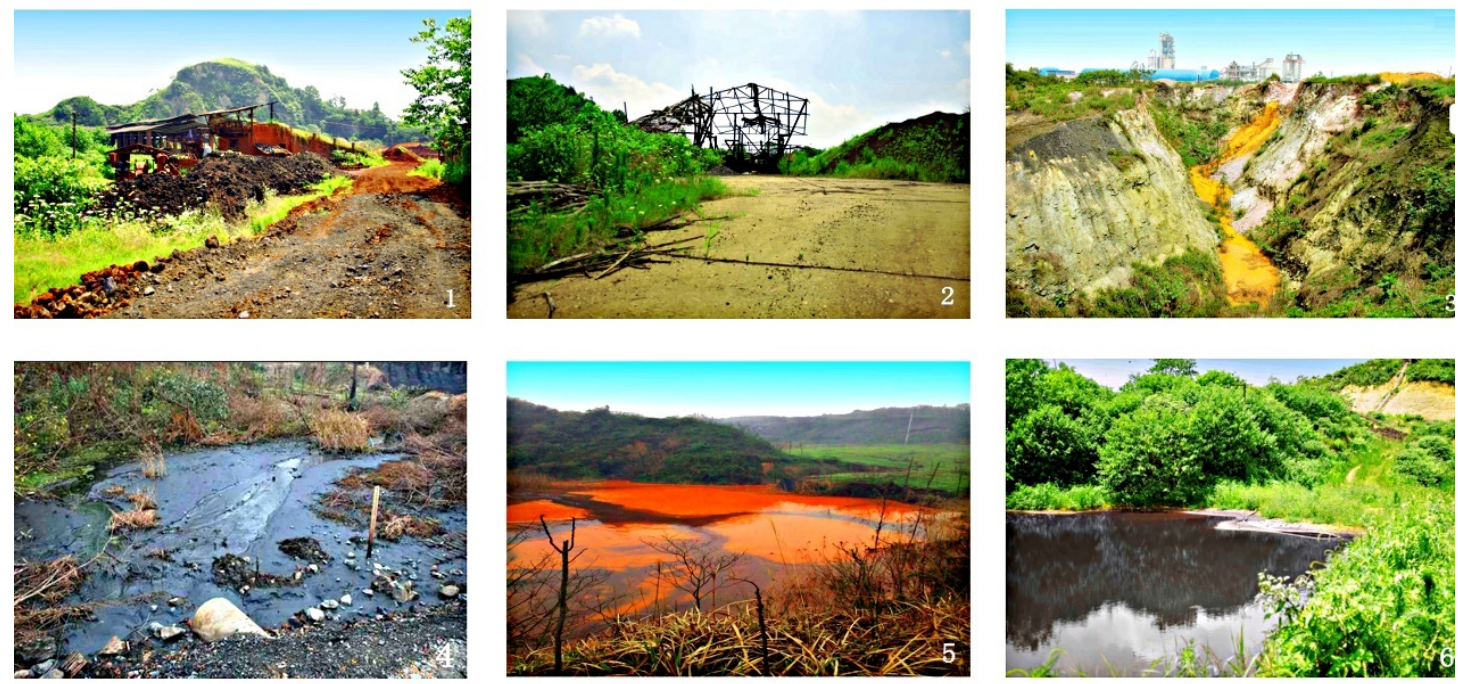

Figure 1. Overview of the study area. (1). Abandoned mining enterprise. (2). Slag stacking site. (3). Current situation of soil erosion. (4). Current situation of sewage discharge. (5). Contaminated wetland. (6). Contaminated wetland.

\subsection{Ecological Restoration Plan}

The heavy metal pollution area of Xiangtan Manganese Mine is mainly formed by the accumulation of slag in different years. The primary soil has been located dozens of meters below the slag. The slag mounds were selected for ecological restoration in 2015, and it is located in the former Qingshan dew mining area of the Xiangtan manganese mine. The implementation plan of ecological restoration consists of three parts: (1) Vegetation restoration and reconstruction of the slag mounds around the wetlands. (2) Establishment of the ecological interception system of the slope around the wetlands. (3) Establishment of the artificial wetland system to a complete wetland ecological restoration system.

\subsubsection{Restoration of Mountains Surrounding the Wetland}

The restoration project covers two adjacent natural wetlands and surrounding slag mounds. The area of $A$ is $4450 \mathrm{~m}^{2}$ and that of $B$ is $6952 \mathrm{~m}^{2}$. The two wetlands are separated by a mountain and are not connected to each other.

\subsubsection{Ground Ecological Restoration Preparation}

(1) Repair plant screening and the construction of plant resource library

The existing terrestrial plant resources in the mining area are collected to establish a restoration plant selection and evaluation system, a spring and summer plant community dominated by wild herbs, and long-term plant community dominated by artificial planting of ornamental plants. Four types of plant communities are suitable for different seasons; the functions of the natural ecosystem are used to attract insects and birds to form a relatively complete and complex ecosystem. This can effectively reduce soil loss and surface runoff and reduce the environmental heavy metal pollution.

\section{(2) Construction of the surface runoff ecological interception system for polluted soil}

Heavy metal pollution is mainly spread around wetlands through soil loss and surface runoff. There are two ways to control the spread of pollution with the surface runoff: (1) Establishing annular ecological water retaining ditches along the mountain can effectively prevent heavy metal pollution from entering the surrounding environment, promote the infiltration of heavy metals with the rain, and reduce heavy metal pollution to soil [25]. In theory, the more retaining ditch, the better the seepage effect, but characterized by the 
greater engineering cost. (2) Setting up spiral ecological ditches along the mountain to strengthen infiltration and lead excess water into the reserve treatment tank. Through chemical and biological methods, toxicity is reduced and precipitation is produced, which has the characteristics of low engineering cost (shown in Figures 2 and 3).

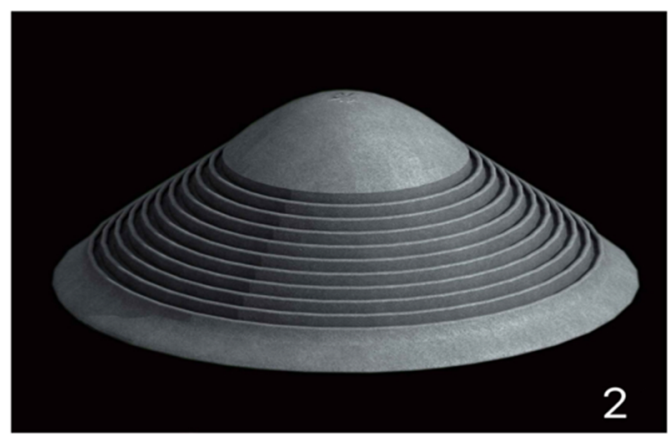

Figure 2. Initial scheme indication of interception system (retaining mode).

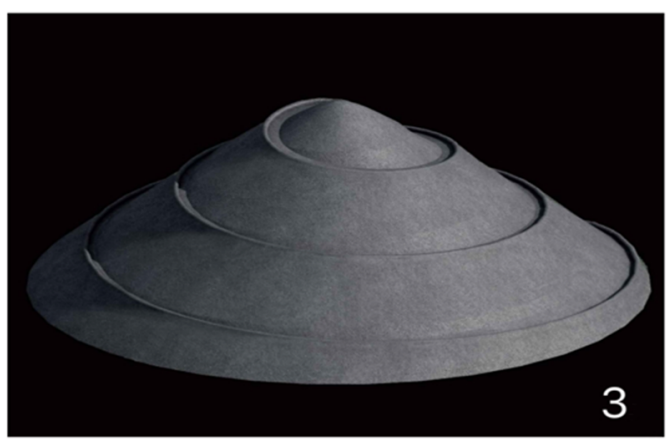

Figure 3. Final scheme indication of interception system (gutter mode).

(3) Construction of the artificial wetland system

In the ecological restoration of artificial wetland, rational allocation of plants and efficient allocation of microorganisms and micro-animals can improve the micro-ecological environment of plant roots and improve the ability of organisms and ecosystems to resist heavy metal pollutants. The terrestrial plant wetland system is introduced to enrich plant resources, solve the problem of limited plant resources in winter, develop technologies to cultivate various ornamental plants, and realize multiple benefits of pollution control, pollution recycling, and economic proliferation.

\subsubsection{Wetland Ecological Restoration was Implemented}

\section{(1) Repair plant screening}

According to the conclusion of preliminary research and potted experiments, the selected tree species must have the following characteristics [26-32]: (1) Strong resistance to heavy metal stress, (2) Ability to absorb rich manganese elements and large biomass, (3) Aesthetic value and economic value; (4) Ability to adapt to the alternate dry and wet growth environment and resistance to high temperature. The final plant species for mountain restoration are: Koelreuteria paniculata, Paulownia fortunei, Cinnamomum camphora, Castanopsis fissa, Elaeocarpus decipiens (as shown in Figure 4), and plant species for wetland restoration include: Canna warscewiezii, Nerium oleander, Arundo donax, Thalia dealbata, Pontederia cordata, Boehmeria, Softstem bulrush, Iris germanica, Acorus Calamus, Typha orientalis, and Phragmites australis, which are planted in wetland A and B. 

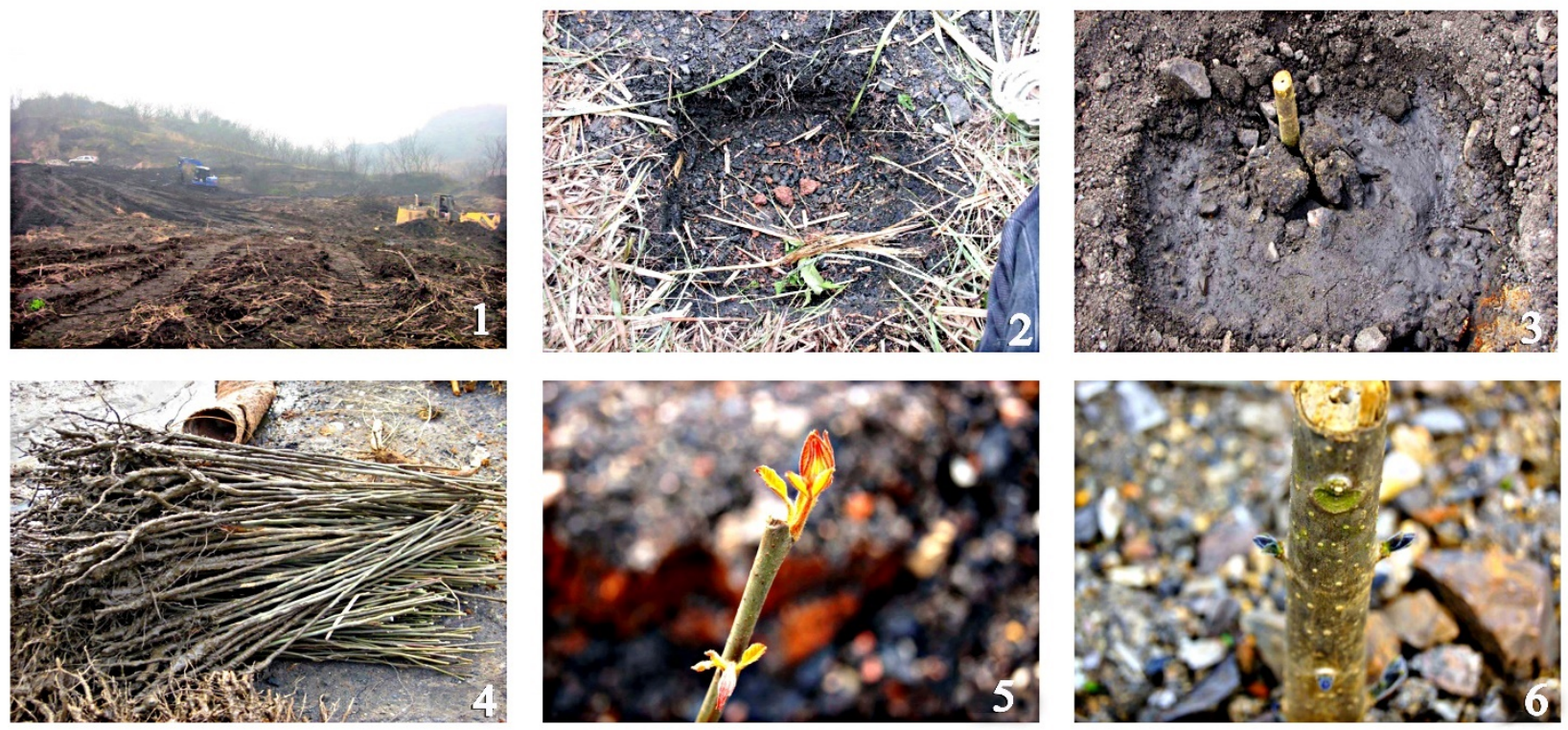

Figure 4. (1). Site cleaning. (2). planting hole. (3). ecological restoration plant. (4). ecological restoration plant. (5). Kolreuteria paniculate. (6). Paolownia fortunci.

(2) Polluted soil surface runoff ecological interception zone project

The ecological interception zone project consists of two blocks: (1) surface runoff collection system; (2) surface runoff treatment system.

Surface runoff collection system adopts the above ecological diversion ditch scheme. According to Sun Li and the study of the wetland plants on the removal of heavy metal pollution, pebbles are at the bottom, large-capacity adsorption filling and sand are in the middle level, and planting shrubs and herbs are at the upper layer. According to the above research and the potted plant experimental conclusion, and based on tolerance, economic, and aesthetic value of heavy metals, the following 11 plants are selected for the wetland's restoration: Canna warscewiezii, Nerium oleander, Arundo donax, Thalia dealbata, Pontederia cordata, Boehmeria, Softstem bulrush, Iris germanica, Acorus calamus, Typha orientalis, and Phragmites australis. Gravel and sand are set inside the ecological interception system for the adsorption and precipitation of heavy metals. The ecological interception zone becomes a first-level treatment unit for wetland landscape restoration.

The surface runoff treatment system is located in the catchment, including three artificial wetland modules. Based on the permeable reaction wall technology, each module has a different matrix filler. Eleven kinds of plants are planted on the surface, and the pollution is finally controlled through physical, chemical, and biological methods. The heavy metal purification effect is good (shown in Figure 5).

\subsection{Measurement of Heavy Metal Content}

Plant sampling plan: sampling of land plants for ecological restoration, select restoration plants, and sample the leaves, branches, stems, barks, and roots. Sample $1 \mathrm{~kg}$ respectively according to diameter $\geq$ large root, medium root, small root, thin root, $0.5 \mathrm{~cm}$, $0.2 \sim 0.5 \mathrm{~cm}, 0.1 \sim 0.2 \mathrm{~cm}, \leq 0.2 \mathrm{~cm}$ and take them back to the laboratory for testing. In the wetland plant sampling, three plants of each kind are taken, the whole plant is taken out from the wetland, and integrity of the root is maintained. The plants are taken back to the laboratory for cleaning, and the above and below ground parts of the plants are separated from the base of the plants. Plant samples shall be taken back to the laboratory and dried in the oven for $24 \mathrm{~h}$ to constant weight. The dried samples are pulverized and the powder are put into the aluminum box. Then, $2 \mathrm{~g}$ of samples are put into the porcelain crucible, and the horse boiler is heated to $300{ }^{\circ} \mathrm{C}$ for about half an hour to smoke, then the temperature is turned to $500{ }^{\circ} \mathrm{C}$ for $2 \mathrm{~h} .2 \mathrm{~mL}$ of 1:1 hydrochloric acid is used for cooling. The ashes are 
dissolved and filtered in a $100 \mathrm{~L}$ volumetric bottle. Deionized ultra-pure water is used to set the line. Finally, the heavy metal content in plant samples $(\mathrm{mg} / \mathrm{Kg})$ is taken. In addition, the plant heavy metal concentration coefficient and the operation coefficient of heavy metal in plants are as follows:

Concentration coefficient $(\mathrm{BAC})=$ in plant pollutant concentration/intrasoil pollution concentration

Operating coefficient $(\mathrm{BTC})=$ aboveground partial heavy metal content $/$ root heavy metal content
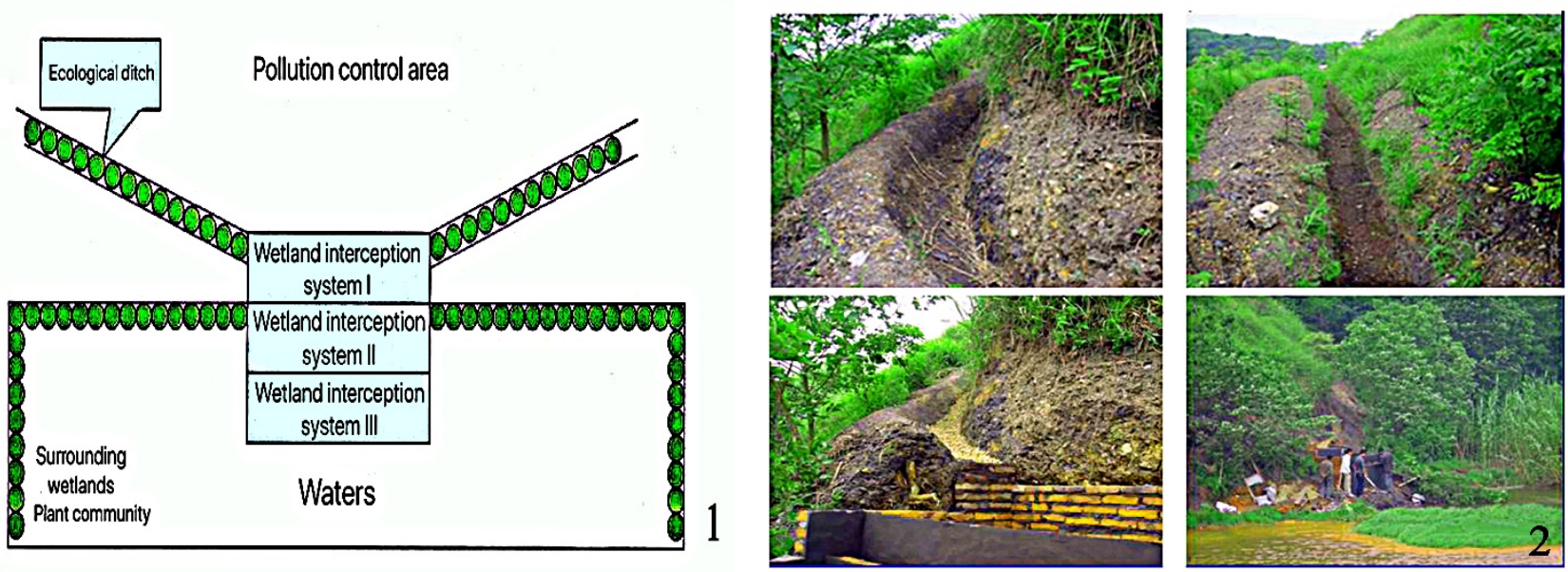

Figure 5. Ecological interception and restoration system. (1). Engineering Schematic Drawing. (2). Engineering Site of the Ecological Interception Zone.

Soil sampling scheme: according to the principle of availability, representativeness, and uniformity, soil samples were collected in 2019 and 2020. 9 samples in four directions of the wetland and 4 soil samples with GPS with $3 \sim 5 \mathrm{~m}$ accuracy was collected. Three samples were taken and fully mixed every $50 \sim 100 \mathrm{~m}$ to form a complete soil sample. All soil samples are packaged in disposable polyethylene bags with detailed information (landscape type, soil type, vegetation cover) to bring the samples back to the laboratory under natural conditions. A total of 144 surface samples $(0 \sim 20 \mathrm{~cm})$ were collected for trial.

Debris was removed after air drying and grinding. The soil in the sample was further ground until it can pass through a $0.149 \mathrm{~mm}$ nylon sieve for soil heavy metal measurement. The soil samples were digested at high temperature for $6 \mathrm{~h}$ by a mixture of nitric acid, hydrofluoric acid, and perchloric acid. Then they were determined by inductively coupled plasma atomic emission spectrometry (Hitachi-4010, produced in Japan). For the determination results, parallel tests and standard control (Chinese Academy of metrology gbw-07401) were used to evaluate the quality assurance and control. The standard recovery was $95.12 \sim 104.47 \%$. The analysis results met the standard requirements of technical code for soil environmental monitoring HJ/T166-2004 issued by the State Environmental Protection Administration.

In order to reflect the soil characteristics and environmental characteristics of the local wetland, the combined outdoor and indoor measurement methods were adopted. The soil $\mathrm{pH}$ meter was used for field measurement. Soil particle composition (sticky particle clay; particle silt; sand particle: sand) was determined by the laboratory laser particle size analyzer (Microtrac S3500, produced in the USA). For soil nutrients, soil organic carbon (Soil organic carbon, $\mathrm{SOC}$ ), nitrate nitrogen $\left(\mathrm{NO}_{3}-\mathrm{N}\right)$, and fast acting phosphorus (AP) were used. Organic carbon removed soil calcium carbonate with soil hydrochloric acid, total organic carbon analyzer (HT1300, Jena) was used. $\mathrm{NO}_{3}-\mathrm{N}$ was determined by UV spectrophotometry. Fast-acting phosphorus was determined by photoelectric specific color method. 


\subsection{Statistics and Analysis Methods}

The basic data was collected and sorted with Excel 2010 first, then the significant differences of all statistical tests were estimated at a significant level of $p<0.05$. Excel 2010 was used for statistical data processing, and SPSS18.0 was used for mean comparison analysis. The statistical maps are drawn according to the collated data.

\section{Results}

\subsection{Soil Physical and Chemical Properties}

Soil is the substrate for plant growth and the most important place for plants to absorb nutrients and water. The changes of the physical and chemical properties of soil play a very important role in the structure and variation of plant population and community. SOC, NO3-N, AP, pH, and soil particle composition (clay, silt, sand) status are shown in Table 1 . The physical and chemical properties of slag heaps in different ages vary greatly. Due to random stacking, the distribution law was not obvious. Among them, $\mathrm{NO}_{3}-\mathrm{N}, \mathrm{AP}$, SOC, K of the new slag mounds are $0.661 \%, 0.4225 \%, 9.335 \%$, and $3.352 \%$ respectively. It can be seen from Table 1 that the soil properties have changed significantly after artificial restoration, and that there was obvious improvement of soil texture is obvious, which verifies the necessity of artificial restoration.

Table 1. Soil physical and chemical properties (\%).

\begin{tabular}{|c|c|c|c|c|c|c|c|c|c|}
\hline & & $\mathrm{NO}_{3}-\mathrm{N}$ & AP & SOC & $\mathbf{K}$ & $\mathrm{pH}$ & $<0.002 \mathrm{~mm}$ Clay & $0.002-0.02 \mathrm{~mm}$ Silt & $0.02-2 \mathrm{~mm}$ Sand \\
\hline \multirow{3}{*}{ Ecological restoration sites } & Mean & $1.202^{\mathrm{a}}$ & $0.932^{\mathrm{a}}$ & $30.048^{\mathrm{a}}$ & $5.945^{\mathrm{a}}$ & $5.03^{a}$ & $26.514^{\mathrm{a}}$ & $41.708^{a}$ & $31.778^{\mathrm{a}}$ \\
\hline & $P$ & 0.02 & 0.001 & 0.001 & 0.001 & 0.001 & 0.002 & 0.004 & 0.006 \\
\hline & $\mathrm{F}_{0.05}$ & 2.56 & 9.02 & 3.88 & 7.002 & 15.27 & 5.611 & 4.579 & 5.021 \\
\hline \multirow{3}{*}{ Non ecological restoration sites } & Mean & $0.710^{\mathrm{b}}$ & $0.530^{\mathrm{b}}$ & $15.239^{b}$ & $5.466^{\mathrm{b}}$ & $4.380^{\mathrm{b}}$ & $51.397^{b}$ & $31.890^{\mathrm{b}}$ & $16.713^{b}$ \\
\hline & $P$ & 0.01 & 0.001 & 0.001 & 0.001 & 0.001 & 0.002 & 0.004 & 0.006 \\
\hline & $\mathrm{F}_{0.05}$ & 0.16 & 0.11 & 5.07 & 2.08 & 1.02 & 10.245 & 3.452 & 1.498 \\
\hline
\end{tabular}

Note: Different lowercase letters in the same column indicate significant differences.

\subsection{Soil Content of Heavy Metals}

It can be seen from Table 2 that, with the exception of $\mathrm{Cu}$, the contents of $\mathrm{Cd}, \mathrm{Zn}$, and $\mathrm{Pb}$ in the soil of the manganese ore contaminated sites are significantly higher than the values in the national level III standard for soil environmental quality. After ecological restoration, all indicators have been significantly improved, but they are still significantly higher than the national level III standard. The background values of Mn and Fe in the areas without heavy metal pollution near the manganese ore pollution area are $688.578 \mathrm{mg} / \mathrm{kg}$ and $3068.567 \mathrm{mg} / \mathrm{kg}$ respectively. After ecological restoration, the content of $\mathrm{Mn}$ in soil is still 26.22 times that of the background value, and the content of Fe is 3.44 times that of the background value.

Table 2. Soil content of heavy metals.

\begin{tabular}{|c|c|c|c|c|c|c|c|c|}
\hline & & $\mathrm{Mn}(\mathrm{mg} / \mathrm{kg})$ & $\mathrm{Fe}(\mathrm{mg} / \mathrm{kg})$ & $\mathrm{Cu}(\mathrm{mg} / \mathrm{kg})$ & $\mathrm{Zn}(\mathrm{mg} / \mathrm{kg})$ & $\mathrm{Pb}(\mathrm{mg} / \mathrm{kg})$ & $\mathrm{Cd}(\mathrm{mg} / \mathrm{kg})$ & $\mathrm{pH}$ \\
\hline \multirow{3}{*}{$\begin{array}{l}\text { Ecological restoration } \\
\text { sites }\end{array}$} & Mean & $18,056.942^{a}$ & $10,562.488^{a}$ & $13.094^{\mathrm{a}}$ & $3222.432^{\mathrm{a}}$ & $3194.613^{a}$ & $32.926^{a}$ & $5.037^{\mathrm{a}}$ \\
\hline & $P$ & 0.000 & 0.000 & 0.004 & 0.000 & 0.000 & 0.000 & 0.000 \\
\hline & $\mathrm{F}$ & 184.190 & 133,424 & 3.381 & 27.902 & 31.231 & 7.76 & 0.568 \\
\hline \multirow{3}{*}{$\begin{array}{l}\text { Non ecological } \\
\text { restoration sites }\end{array}$} & Mean & $19,688.578^{b}$ & $13,068.567^{b}$ & $18.004^{b}$ & $3489.871^{b}$ & $3514.735^{b}$ & $40.954^{b}$ & $4.47^{b}$ \\
\hline & $P$ & 0.000 & 0.000 & 0.004 & 0.000 & 0.000 & 0.000 & 0.000 \\
\hline & $\mathrm{F}$ & 199.152 & 162.025 & 3.565 & 37.451 & 36.980 & 12.667 & 0.523 \\
\hline $\begin{array}{l}\text { National standard } \\
\text { levels (Grade III) }\end{array}$ & & - & - & 400 & 500 & 500 & 1.0 & - \\
\hline
\end{tabular}

Note: Different lowercase letters in the same column indicate significant differences. 


\subsection{Screening of the Plant Survival Status}

Among the trees selected for mountain restoration, only Elaeocarpus decipiens and Koelreuteria paniculata survived and grew well; only one Cinnamomum camphora survived, and Castanopsis fissa and Paulownia fortunei all died. Only Nerium oleander and Ligustrum quihoui in the collection system survived. Hydrocotyle vulgari and Ligustrum quihoui in the processing system all died, Arundo donax and Acorus calamus did not grow well, and Softstem bulrush, Iris germanica, Phragmites australis, Pontederia cordata, and Canna warscewiezii survived and grew well. The content of heavy metals in the roots of the dead plants is much greater than that on the ground. Plant transfer and utilization of heavy metals is very weak, and heavy metal elements accumulate in plant roots, causing plant poisoning.

\subsection{Heavy Metal Content in the Plant Body}

(1) Heavy metal content in the land plant roots

Table 3 shows the heavy metal content of the roots of Koelreuteria paniculata and Elaeocarpus decipiens. The content of manganese in the roots of Koelreuteria paniculata increases gradually from big root to fine root. The content of manganese in the fine roots was significantly higher than other parts of the roots $(p<0.05)$. However, the content of manganese in the roots of Elaeocarpus decipiens decreases gradually from big root to fine root. The content of manganese in the fine roots is significantly lower than other parts of the roots $(p<0.05)$. The content of $\mathrm{Fe}$ and $\mathrm{Cu}$ in Koelreuteria paniculata roots increased from big to fine roots, with significant differences from other parts $(p<0.05)$, and the content of $\mathrm{Fe}$ and $\mathrm{Cu}$ in Elaeocarpus decipiens had the same trend to Koelreuteria paniculata. The difference of $\mathrm{Zn}$ and $\mathrm{Pb}$ were not significant in big root of Koelreuteria paniculata, middle root and small root, but their content in fine root is significantly higher than the other 3 parts. The difference of $\mathrm{Zn}$ and $\mathrm{Pb}$ was significant in big root of Elaeocarpus decipiens, middle root, and small root, from large root to fine root. The content of $\mathrm{Cd}$ in four parts of roots of Koelreuteria paniculata and Elaeocarpus decipiens roots was low and the difference was not significant $(p>0.05)$.

Table 3. The heavy metal content in root of plantation $(\mathrm{mg} / \mathrm{kg})$.

\begin{tabular}{|c|c|c|c|c|c|c|c|}
\hline & Part & Mn & $\mathrm{Fe}$ & $\mathrm{Cu}$ & $\mathrm{Zn}$ & $\mathbf{P b}$ & $\mathrm{Cd}$ \\
\hline \multirow{4}{*}{$\begin{array}{c}\text { Koelreuteria } \\
\text { paniculata }\end{array}$} & Big root & $240.29 \pm 23.33 a$ & $104.95 \pm 9.23 a$ & $4.06 \pm 0.79 a$ & $24.95 \pm 4.85 a$ & $4.69 \pm 0.64 a$ & $0.38 \pm 0.05 a$ \\
\hline & Medium root & $248.28 \pm 41.88 \mathrm{a}$ & $173.27 \pm 41.29 b$ & $5.82 \pm 0.34 b$ & $25.97 \pm 0.83 a$ & $4.81 \pm 1.41 \mathrm{a}$ & $0.45 \pm 0.06 a$ \\
\hline & Small root & $295.89 \pm 8.72 a$ & $331.58 \pm 181.32 c$ & $6.21 \pm 0.45 c$ & $26.92 \pm 4.12 \mathrm{a}$ & $5.44 \pm 1.17 a$ & $0.42 \pm 0.025 a$ \\
\hline & Fine root & $419.28 \pm 71.02 \mathrm{~b}$ & $530.56 \pm 206.66 \mathrm{~d}$ & $9.26 \pm 2.30 \mathrm{~d}$ & $37.83 \pm 4.05 b$ & $9.49 \pm 1.72 b$ & $0.42 \pm 0.18 a$ \\
\hline \multirow{4}{*}{$\begin{array}{l}\text { Elaeocarpus } \\
\text { sylvestris }\end{array}$} & Big root & $433.65 \pm 26.05 a$ & $122.11 \pm 33.18 \mathrm{a}$ & $2.53 \pm 0.27 \mathrm{a}$ & $8.44 \pm 2.53 a$ & $2.95 \pm 0.35 \mathrm{a}$ & $0.98 \pm 0.16 a$ \\
\hline & Medium root & $345.84 \pm 48.09 b$ & $173.32 \pm 66.14 b$ & $4.84 \pm 0.21 b$ & $10.31 \pm 1.22 \mathrm{~b}$ & $3.20 \pm 0.23 b$ & $0.76 \pm 0.09 a$ \\
\hline & Small root & $335.42 \pm 26.63 b$ & $524.56 \pm 128.19 c$ & $5.93 \pm 0.17 c$ & $15.79 \pm 0.95 c$ & $3.78 \pm 0.29 \mathrm{c}$ & $0.76 \pm 0.07 a$ \\
\hline & Fine root & $286.31 \pm 86.96 c$ & $689.11 \pm 141.87 \mathrm{~d}$ & $7.93 \pm 0.74 \mathrm{~d}$ & $25.01 \pm 2.30 d$ & $7.80 \pm 0.85 b$ & $1.04 \pm 0.04 a$ \\
\hline $\begin{array}{c}\text { Soil heavy } \\
\text { metal contents }\end{array}$ & & $18,056 \pm 109.45 a$ & $10,562.49 \pm 163.66 a$ & $13.10 \pm 3.65 a$ & $3222.43 \pm 26.37 a$ & $3194.613 \pm 7.52 a$ & $32.962 \pm 0.15 a$ \\
\hline $\begin{array}{l}\text { National standard } \\
\text { levels (Grade III) }\end{array}$ & & - & - & 400 & 500 & 500 & 1.0 \\
\hline
\end{tabular}

Note: Different lowercase letters in the same column indicate significant differences.

(2) Heavy metal content in the wetland plant

Eleven species of wetland plants were selected for wetland restoration and planted in ecological interception zone in natural wetlands in restoration project area. $\mathrm{Mn}, \mathrm{Cu}, \mathrm{Zn}$, and $\mathrm{Cd}$ were detected in wetland plants. Figure 6 shows the content of above-ground and underground heavy metals of wetland plants. Canna warscewiezii, Nerium oleander, Arundo donax, Thalia dealbata, Pontederia cordata, Boehmeria, Softstem bulrush, Iris germanica, Acorus calamus, Typha orientalis, and Phragmites australis's above-ground Mn content is significantly higher than the underground Mn content $(p<0.05)$; the Mn content of Nerium oleander is not significantly different from its underground Mn content $(p>0.05)$. Among the 11 kinds of plants, the Arundo donax's content is highest and significantly higher than the 10 other plants; Canna warscewiezii, Piracuda grass, and Boehmeria's Mn content is less than Thalia dealbata's, but the three plants are not significantly different than the other 7 plants, Nerium 
oleander's Mn content is significantly less than Canna warscewiezii and other three plants, but significantly greater than the other 5 plants, Softstem bulrush, Iris germanica, and Acorus calamus is significantly less than Nerium oleander but significantly greater than Arundo donax; Phragmites australis is the least Mn content of all planting plants. The Mn content in the plant from high to low order is as follows: Canna warscewiezii $>$ Thalia dealbata $>$ Boehmeria $>$ Pontederia cordata $>$ Typha orientalis $>$ Nerium oleander $>$ Softstem bulrush $>$ Iris germanica $>$ Acorus calamus $>$ Arundo donax $>$ Phragmites australis.

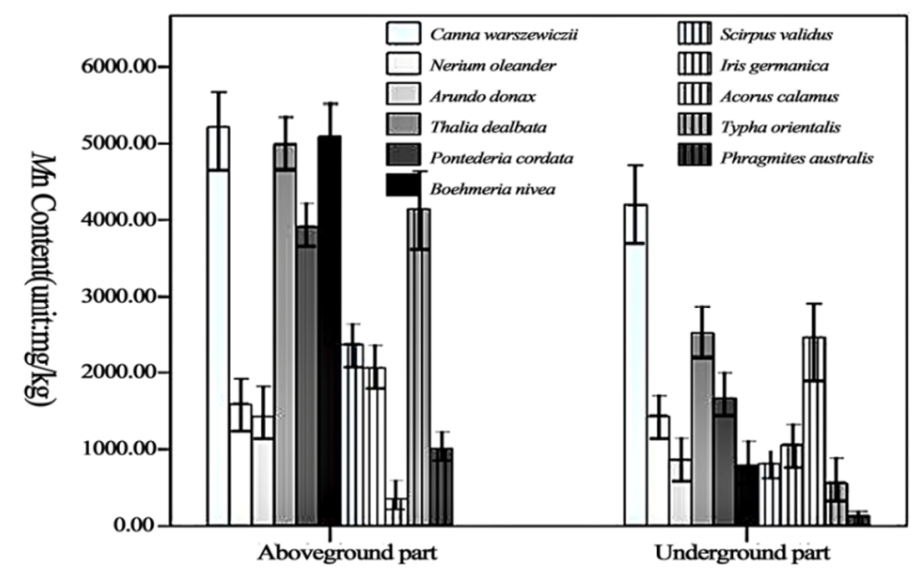

(a) Mn content in Wetland plants on the ground and underground

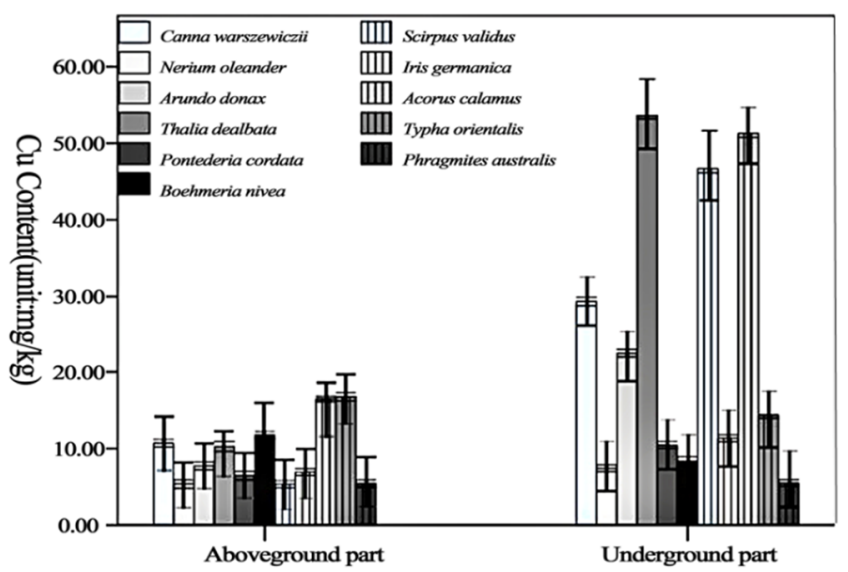

(b) Cu content in Wetland plants on the ground and underground.

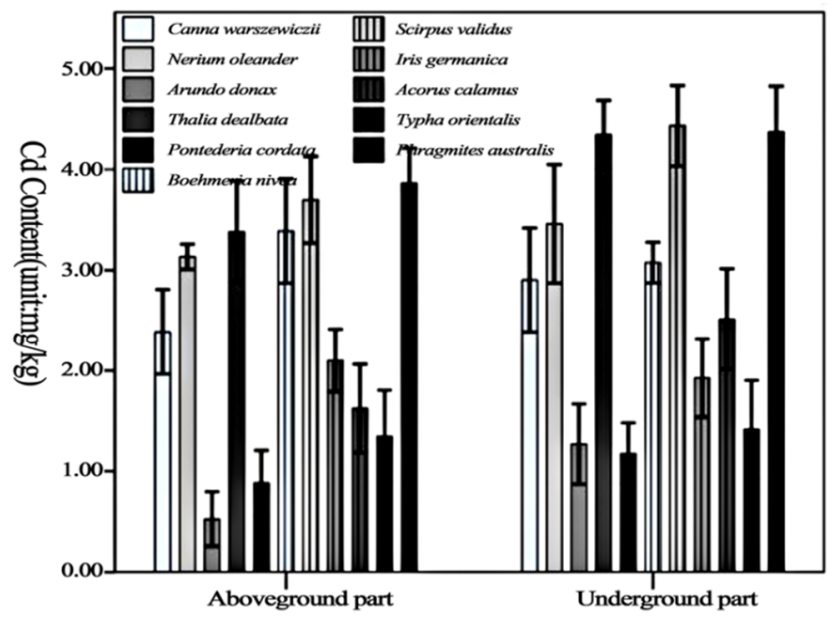

(d) Cd content in Wetland plants on the ground and underground.

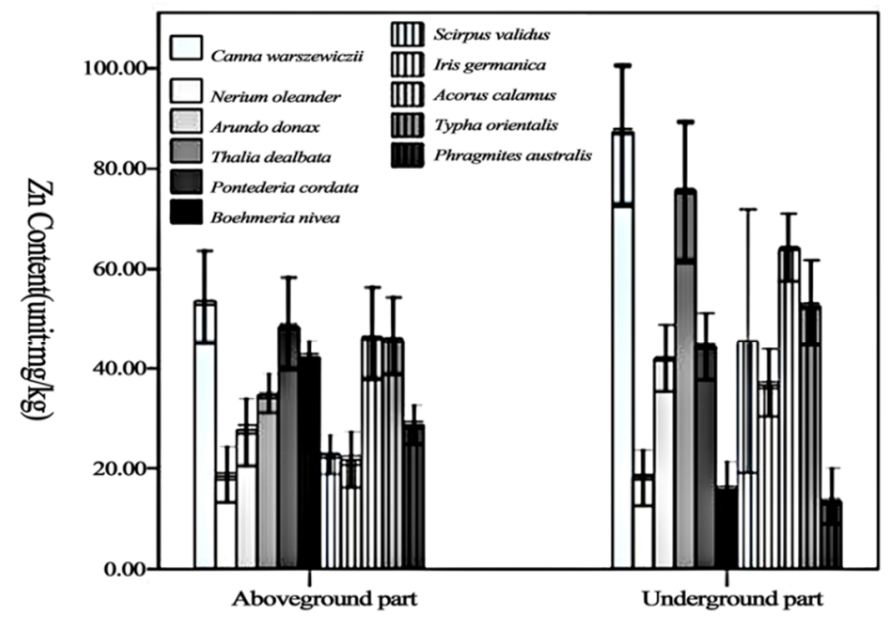

(c) $\mathrm{Zn}$ content in Wetland plants on the ground and underground.

Figure 6. The accumulation of heavy metal content in Wetland plants on the ground and underground.

The experiment shows that the maximum transfer coefficient of $\mathrm{Mn}$ in wetland plant BTF is Phragmites australis, up to 7.55, and its transfer ability of its underground parts to the aboveground parts of the plant body is very strong. The minimum BTF is the Acorus calamus, value is 0.14 , and its ability to transfer from underground parts to the aboveground parts is very weak. Maximum BAF is Canna warscewiezii, up to 7.53, which has a strong enrichment capacity for the soil of Mn. BTF from large to small order: Phragmites australis $>$ Typha orientalis $>$ Boehmeria $>$ Softstem bulrush $>$ Pontederia cordata $>$ Thalia dealbata $>$ Iris germanica $>$ Arundo donax $>$ Canna warscewiezii $>$ Nerium oleander $>$ Acorus calamus, BAF from large to small order is: Canna warscewiezii $>$ Boehmeria $>$ Thalia dealbata $>$ Pontederia cordata $>$ Typha orientalis $>$ Softstem bulrush $>$ Nerium oleander $>$ Iris germanica $>$ Acorus calamus $>$ Arundo donax $>$ Phragmites australis. 


\subsection{Control Status of Heavy Metals Pollution}

The content of heavy metal elements detected in the Class I wetland unit is significantly lower than the value of the unit intake. The contents of $\mathrm{Mn}, \mathrm{Pb}, \mathrm{Zn}, \mathrm{Cd}$, and $\mathrm{Cu}$ have decreased by $11.5 \%, 19.3 \%, 82.0 \%, 33.3 \%$, and $80.0 \%$, respectively. Among them, the removal rate of $\mathrm{Zn}$ and $\mathrm{Cu}$ was the highest, and the water outlet of the Class I wetland unit is lower than the national discharge standard (Table 4). In general, the treatment effect of Grade I wetland unit treatment is not ideal, especially the removal rate of manganese and lead is very low, and these two elements' contents are still far higher than the national standards. During field observation, the water quality of the well out of the primary wetland unit is very clear. It is said that the turbidity removal capacity of this unit is very strong, and the main reason for the low heavy metal removal ability is that the adsorption capacity of the selected filling in the unit is small. In view of the construction cost of the treatment system, the main filler of this unit is sand, gravel, and peat soil. The filtration performance of peat soil is very good, but the adsorption capacity of heavy metal ions is small. In addition, plant roots are underdeveloped and microbial activity is low. Therefore, the treatment effect of removing manganese and lead in the primary wetland unit is not significant. The biological role of the ecological interception and processing system is very important. It is necessary to carry out in-depth analysis and research in the progress of the system. Compared with the primary unit, the effect of removing the heavy metal elements in the secondary wetland unit is very significant. With the effluent content of the primary unit as the base, the removal rate of all the detected heavy metal elements has exceeded $99 \%$. The content of manganese effluent in the secondary wetland unit is not only far lower than the value of the primary treatment unit but also several times below the standards stipulated by the state.

Table 4. Heavy metal content in water samples collected in the outlet of treatment cells $\left(\mathrm{mg} / \mathrm{kg}^{-1}\right)$.

\begin{tabular}{ccccccc}
\hline Sample Type & Sampling Point & $\mathbf{M n}$ & $\mathbf{P b}$ & $\mathbf{Z n}$ & $\mathbf{C d}$ & $\mathbf{C u}$ \\
\hline Soil samples & Total soil content & $18,056.9$ & 3194.6 & 3222.4 & 32.9 & 13.1 \\
\hline & Control (no interception) & 27.03 & 0.9 & 2.65 & 0.08 & 0.02 \\
& Treatment system import & 26.77 & 0.57 & 2.66 & 0.06 & 0.05 \\
water samples & Primary wetland unit & 23.7 & 0.46 & 0.48 & 0.04 & 0.01 \\
& Secondary wetland unit & 0.1 & 0.1 & 0.05 & - & $/$ \\
& Tertiary wetland unit & $/$ & $/$ & 1 & 0.01 & 0.5 \\
\hline
\end{tabular}

Heavy metal content in the water samples in the wetland does not change much. Although the pollution from the surrounding slag mounds has been cut off, mainly because of a lot of heavy metal sludge, after the detection of heavy metal content in the plant, Canna warscewiezii, Boehmeria, and other parts of the ground manganese content reached $4000 \mathrm{mg} / \mathrm{kg}$. It shows that aquatic plants still reduce the total amount of heavy metals in the wetlands.

\section{Discussion}

Ecological restoration planting plants can effectively absorb the heavy metals of the soil during the process of growth; the main reason is that the plant root secretions can regulate the soil environment, activate the heavy metal elements, make heavy metal elements gradually dissolve, and form organic matter and heavy metal compounds. Increasing the biological activity of heavy metals can promote plant roots to effectively transfer heavy metal compounds to the plant. The accumulation of Fe and Mn in the slag soil in the study area is the highest, while $\mathrm{Pb}$ and $\mathrm{Cd}$ are the lowest. Fe and Mn content are the lowest in all plants, indicating that plant growth is closely related to the heavy metal content in the environment. There are obvious differences between the absorption capacity of two plants planted on land and 11 plants planted in wetlands and different heavy metals, and the 
content of heavy metals varies in different parts and root systems. Except Mn, the content of $\mathrm{Cu}, \mathrm{Zn}$, and $\mathrm{Cd}$ in the roots is greater than they are in the above-ground part, indicating that wetland plants avoid the damage of heavy metals to the above-ground tissues by enriching the root system.

The experimental results of plant growth in manganese polluted wetland showed that the survival rate of Hydrocotyle vulgaris was low, the growth of Arundo donax and Acorus calamus decreased, but the growth of Thalia dealbata, Boehmeria nivea, Canna indica, Phragmites australis, Typha orientalis, Nerium oleander, Pontederia cordata, Scirpus validus and Iris germanica grew well. The results of the demonstration project further prove that the well-growing plants can be used as alternative plants for the leachate collection and treatment system of Xiangtan Manganese Mine contaminated soil.

\section{Conclusions}

During the preliminary study of the heavy metal pollution of manganese ore, the N.L.Nemerow (pollution index) method was used to evaluate the heavy metal pollution of soil from single factor pollution index and comprehensive pollution index. In this way, it not only comprehensively reflects the pollution of different heavy metal elements to the soil but also highlights the pollution of high concentration heavy metal elements with the greatest impact on the soil quality. At the same time, the potential ecological hazard index method was used to evaluate the potential ecological hazard of heavy metal pollution in soil. The results are consistent with those of the isotopic research of Sutkowska, Vladislav Chrastný, Vaněk, Aleš and Rafael Baieta: (1) In the area of deeply buried ore bodies, $90 \%$ of the $\mathrm{HM}$ load was related to anthropogenic sources. $\mathrm{Zn}, \mathrm{Pb}$, and $\mathrm{Cd}$ vertical distributions and the patterns of topsoil pollution differ in terms of types of mined ores. (2) Under relatively comparable $\mathrm{pH}$ conditions, the main soil properties influencing metal migration are total organic carbon and cation exchange capacity. The mobilization of $\mathrm{Pb}, \mathrm{Zn}$, and $\mathrm{Cd}$ in soils depends on the persistence of the metal-containing particles in the atmosphere; the longer the time, the more abundant the stable forms. (3) The pollution decreases with the distance from the slag.

The overall strategy and technical route for the implementation of heavy metal pollution control are: source reduction, process control and intermediate ecological restoration, and terminal interception. The focus of this study is to control the diffusion of heavy metal pollution in the mining area. The technical route is as follows: excavate a fence ditch around the mountain at the bottom of the waste slag stacking mounds, collect the surface runoff and soil leachate of the mountain, and introduce an artificial wetland treatment system with multi-level functional units based on the principle of permeable reaction wall technology. The collected soil leachate and runoff water are purified by using wetland plants with strong absorption capacity and resistance to heavy metal pollution adsorbed and screened by media fillers.

(1) The Mn content of different parts of Koelreuteria paniculata root from high to low order: fine root $>$ small root $>$ medium root $>$ large root. The Mn content of different parts of Elaeocarpus decipiens root from high to low order: large root $>$ medium root $>$ small root $>$ fine root.

(2) The Mn content in wetland restoration plants varies from high to low order is as follows: Canna warscewiezii $>$ Thalia dealbata $>$ Boehmeria $>$ Pontederia cordata $>$ Typha orientalis $>$ Nerium oleander $>$ Softstem bulrush $>$ Iris germanica $>$ Acorus calamus $>$ Arundo donax $>$ Phragmites australis; Internal $\mathrm{Cu}$ content from high to low order is as follows: Acorus calamus $>$ Thalia dealbata $>$ Softstem bulrush $>$ Canna warscewiezii $>$ Typha orientalis $>$ Arundo donax $>$ Boehmeria $>$ Iris germanica $>$ Pontederia cordata $>$ Nerium oleander $>$ Phragmites australis; Zn content from high to low order is as follows: Canna warscewiezii $>$ Acorus calamus $>$ Thalia dealbata $>$ Typha orientalis $>$ Pontederia cordata $>$ Arundo donax $>$ Softstem bulrush $>$ Iris germanica $>$ Boehmeria $>$ Phragmites australis > Nerium oleander; Internal Cd content from high to low order is as follows: Phragmites australis $>$ Softstem bulrush $>$ Thalia dealbata $>$ Nerium oleander $>$ Nerium 
oleander $>$ Boehmeria $>$ Canna warscewiezii $>$ Acorus calamus $>$ Iris germanica $>$ Typha orientalis $>$ Pontederia cordata $>$ Arundo donax.

The contents of manganese in aboveground tissue of wetland plant samples is mostly higher than $1000 \mathrm{mg} / \mathrm{kg}$, and the contents of zinc, copper, and cadmium are also relatively high. The ratio of manganese content in above-ground tissue to root is greater than 1 . The ratio of $\mathrm{Mn}, \mathrm{Zn}, \mathrm{Cu}$, and $\mathrm{Cd}$ contents in the poor growing Acorus calamus and Arundo donax to these heavy metal contents in aboveground tissue to root is less than 1 , which indicates that their ability to transfer and utilize heavy metals is weak, and heavy metals accumulate in roots and cause plant poisoning. The absorption of manganese in the aboveground part of Boehmeria nivea is as high as $217.8 \mathrm{mg} / \mathrm{kg}$, followed by Thalia dealbata, Phragmites australis, and Canna indica. The lowest absorption is Pontederia cordata and Scirpus validus.

(3) The contents of $\mathrm{Mn}, \mathrm{Pb}, \mathrm{Zn}, \mathrm{Cd}$, and $\mathrm{Cu}$ in the soil and wetland in the polluted area far exceed the national standards, which indicates that manganese is not the only polluting element in manganese ore polluted area. In the treatment of heavy metals contaminated area, it is necessary to take appropriate measures to further control the possible harm caused by other heavy metals. The content of $\mathrm{Cu}$ in the water sample in the control area is lower than the national standard. The test data show that the impact of $\mathrm{Cu}$ on the water environment in the manganese ore polluted area does not pose a potential threat.

Soil leakage fluid and surface runoff interception and treatment system in the steep slope slag mountain around the wetland have a strong ability to remove manganese, lead, $\mathrm{Zn}$, and tin. After the purification treatment of the two-level wetland units, the content of all the heavy metal elements detected in the water samples is far lower than the emission standards stipulated by the state. However, due to the short running time of the system, whether the established system can always maintain a high purification rate remains to be seen in further operation.

Suggestion for potential future research:

(4) The N.L.Nemerow (pollution index) method and isotope tracing technology shall be combined to scientifically evaluate the pollution degree of manganese ore polluted area to the surrounding areas.

(5) The evaluation indexes of soil environmental geochemical evaluation shall be used to evaluate the pollution of heavy metals and put forward a more reasonable ecological restoration scheme.

(6) Monitoring of the operation effect of the ecological interception and treatment system should be continued. Further improvement of the design of soil leakage and surface runoff collection and treatment system and further study of the biological role of ecological interception and treatment system should be achieved.

Author Contributions: Project administration and writing—review and editing, Y.L.; experimental data analysis, Y.J. (Yunan Jiao) and Y.J. (Yuqi Jiang); formal analysis, M.Z.; methodology, G.W.; visualization and design of the surface runoff ecological interception system, D.W. and W.X.; investigation, H.L. and Z.X. All authors have read and agreed to the published version of the manuscript.

Funding: This research was funded by the Science and Technology Department of Hunan Province, China (approval No. S2019JJMSXM0531).

Institutional Review Board Statement: The study was conducted according to the guidelines of the Declaration of Helsinki, and approved by the Institutional Review Board-Xiangtan Forestry Bureau.

Informed Consent Statement: Not applicable.

Data Availability Statement: Data supporting reported by http://sthjt.hunan.gov.cn/, (accessed on 5 June 2021).

Acknowledgments: The research was supported by the general projects of the Nature Science Foundation provided by the Science and Technology Department of Hunan Province, China (approval No. S2019JJMSXM0531). Foundation provided by the Science and Technology Department of Hunan 
Province, China (approval No. S2019JJMSXM0531). The authors are grateful to the Forestry Bureau of Hunan Province (FBHP) for providing the case study data. The authors would like to thank the reviewers for helping to substantially improve the quality of the article. The authors would also like to thank the editorial consultant team for reviewing the English language of the manuscript and for their helpful suggestions.

Conflicts of Interest: The authors declare no conflict of interest.

\section{References}

1. Wang, H.; Hashimoto, S.; Moriguchi, Y.; Yue, Q.; Lu, Z. Resource use in growing China: Past trends, influence factors, and future demand. J. Ind. Ecol. 2012, 16, 481-492. [CrossRef]

2. Xiang, J.; Chen, J.; Bagas, L.; Li, S.; Wei, H.; Chen, B. Southern China's manganese resource assessment: An overview of resource status, mineral system, and prediction model. Ore Geol. Rev. 2020, 116, 103261. [CrossRef]

3. Jordan, G. Sustainable mineral resources management: From regional mineral resources exploration to spatial contamination risk assessment of mining. Environ. Geol. 2009, 58, 153. [CrossRef]

4. Yang, Y.Y.; Xu, Y.S.; Shen, S.L.; Yuan, Y.; Yin, Z.Y. Mining-induced geo-hazards with environmental protection measures in Yunnan, China: An overview. Bull. Eng. Geol. Environ. 2015, 74, 141-150. [CrossRef]

5. Todorova, E.; Kostadinova, A. Risks of environmental pollution from mining waste from ore-containing Cu processing. J. Environ. Protect. Ecol. 2019, 20, 397-403.

6. Efendieva, Z.J.; Khalifazade, C.M. Economic problems and environmental challenges in ore mining in Azerbaijan. J. Min. Sci. 2018, 54, 166-172. [CrossRef]

7. Attuquayefio, D.K.; Owusu, E.H.; Ofori, B.Y. Impact of mining and forest regeneration on small mammal biodiversity in the Western Region of Ghana. Environ. Monit. Assess. 2017, 189, 237. [CrossRef] [PubMed]

8. Kayet, N.; Pathak, K.; Chakrabarty, A.; Kumar, S.; Singh, C.P.; Chowdary, V.M. Assessment of mining activities on tree species and diversity in hilltop mining areas using Hyperion and Landsat data. Environ. Sci. Pollut. Res. 2020, 27, 42750-42766. [CrossRef]

9. Sutkowska, K.; Teper, L.; Czech, T.; Hulok, T.; Olszak, M.; Zogala, J. Quality of Peri-Urban Soil Developed from Ore-Bearing Carbonates: Heavy Metal Levels and Source Apportionment Assessed Using Pollution Indices. Minerals 2020, 10, 1140. [CrossRef]

10. Tyszka, R.; Pietranik, A.; Potysz, A.; Kierczak, J.; Schulz, B. Experimental simulations of ZnPb slag weathering and its impact on the environment: Effects of acid rain, soil solution, and microbial activity. J. Geochem. Explor. 2021, 228, 106808. [CrossRef]

11. Ettler, V.; Štěpánek, D.; Mihaljevič, M.; Drahota, P.; Jedlicka, R.; Kř́̉bek, B.; Vaněk, A.; Penížek, B.; Sracek, O.; Nyambe, I. Slag dusts from Kabwe (Zambia): Contaminant mineralogy and oral bioaccessibility. Chemosphere 2020, 260, 127642. [CrossRef] [PubMed]

12. Baran, A.; Wieczorek, J.; Mazurek, R.; Urbański, K.; Klimkowicz-Pawlas, A. Potential ecological risk assessment and predicting zinc accumulation in soils. Environ. Geochem. Health 2018, 40, 435-450. [CrossRef] [PubMed]

13. Wieczorek, J.; Baran, A.; Urbański, K.; Mazurek, R.; Klimowicz-Pawlas, A. Assessment of the pollution and ecological risk of lead and cadmium in soils. Environ. Geochem. Health 2018, 40, 2325-2342. [CrossRef] [PubMed]

14. Zang, Z.; Li, Y.; Li, H.; Guo, Z.; Zhang, R. Spatiotemporal variation and pollution assessment of Pb/Zn from smelting activities in China. Int. J. Environ. Res. Public Health 2020, 17, 1968. [CrossRef]

15. Liu, J.; Wang, J.; Zhu, L.; Chen, X.; Ma, Q.; Wang, L.; Wang, X.; Yan, W. A High-Safety and Multifunctional MOFs Modified Aramid Nanofiber Separator for Lithium-Sulfur Batteries. Chem. Eng. J. 2021, 411, 128540. [CrossRef]

16. Vaněk, A.; Grösslová, Z.; Mihaljevič, M.; Ettler, V.; Trubač, J.; Chrastný, V.; Penížek, V.; Teper, L.; Cabala, J.; Voegelin, A.; et al. Thallium isotopes in metallurgical wastes/contaminated soils: A novel tool to trace metal source and behavior. J. Hazard. Mater. 2018, 343, 78-85. [CrossRef] [PubMed]

17. Baieta, R.; Mihaljevič, M.; Ettler, V.; Vaněk, A.; Penížek, V.; Trubač, J.; Kříbek, B.; Ježek, J.; Svoboda, M.; Sracek, O.; et al. Depicting the historical pollution in a Pb-Zn mining/smelting site in Kabwe (Zambia) using tree rings. ADS 2021, 181, 104246.

18. Chrastný, V.; Vaněk, A.; Teper, L.; Cabala, J.; Procházka, J.; Pechar, L.; Drahota, P.; Penížek, V.; Komárek, M.; Novák, M. Geochemical position of $\mathrm{Pb}, \mathrm{Zn}$ and $\mathrm{Cd}$ in soils near the Olkusz mine/smelter, South Poland: Effects of land use, type of contamination and distance from pollution source. Environ. Monit. Assess. 2012, 184, 2517-2536. [CrossRef]

19. Zhu, J.W.; Xiang, Y.C.; Yu, G.H.; Mo, H.W.; Chen, Z. Study on Spatial Distribution of Heavy Metals Pollution in Manganese Mine Land. Environ. Sci. Manag. 2019, 44, 35-38.

20. Fang, X.; Tian, D.L.; Xie, R.X. Soil physical and chemical properties of the wasteland in Xiangtan manganese mine. Acta Ecol. Sin. 2006, 26, 1494-1501.

21. Jiang, F.; Ren, B.; Hursthouse, A.S.; Zhou, Y. Trace metal pollution in topsoil surrounding the Xiangtan manganese mine area (South-Central China): Source identification, spatial distribution and assessment of potential ecological risks. Int. J. Environ. Res. Public Health 2018, 15, 2412. [CrossRef]

22. Shi, X.Y.; Ren, B.Z. Predict three-dimensional soil manganese transport by HYDRUS-1D and spatial interpolation in Xiangtan manganese mine. J. Clean. Product. 2021, 292, 125879. [CrossRef]

23. Zhu, G.H.; Wang, C.; Li, L.; Chen, J.; Wen, Y.; Li, S.Y. Poluution characteristics and ecological risk assessment of soil in xiangtan jinshi manganese mining area. J. Anhui Agric. Sci. 2018, 46, 48-52. 
24. Kandziora-Ciupa, M.; Ciepał, R.; Nadgórska-Socha, A.; Barczyk, G. A comparative study of heavy metal accumulation and antioxidant responses in Vaccinium myrtillus L. leaves in polluted and non-polluted areas. Environ. Sci. Pollut. Res. Int. 2013, 20, 4920-4932. [CrossRef] [PubMed]

25. Robinson, B.H.; Hcblane, M.; Daniel, P.; Robert, R.B.; John, H.K.; Paul, E.H.G. The potential of Thlaspi caerulescens for phytoremediation of contaminatcd soils. Plant Soil 1998, 203, 47-56. [CrossRef]

26. Bai, X.Y.; Liu, H.H.; Hu, H.H.; Qin, F.; Su, X.L. Research progress and development trend of flower phytoremediation technology for heavy metal contaminated soil. J. Anhui Agric. Sci. 2009, 37, 8672-8674.

27. Wu, Z.Q.; Gu, S.Y.; Li, H.Y.; Wang, C.M. Phytoremediation of Heavy Metal S-Contaminated Soils and Hyper-Accumulator's Research Advance. Environ. Sci. Manag. 2007, 3, 65-67.

28. Yang, X.Y.; Lei, H.Q.; Li, F.Y.; Yan, T.J.; Wu, Z.G.; He, J.H. Sieves for ecological restoration of plant species in abandoned alum mines. Sci. Silvae Sin. 2009, 145, 14-18.

29. Tang, S.R.; Wilke, B.M.; Huang, C.Y. The uptake of $\mathrm{Cu}$ by plants dominantly growing on Cu mining spoils along the Yangtze River, the People's Republic of China. Plant Soil 1999, 209, 225-232. [CrossRef]

30. Nadgórska-Socha, A.; Kafel, A.; Kandziora-Ciupa, M.; Gospodarek, J.; Zawisza-Raszka, A. Accumulation of heavy metals and antioxidant responses in Vicia faba plants grown on monometallic contaminated soil. Environ. Sci. Pollut. Res. Int. 2013, 20, 1124-1134. [CrossRef]

31. Ye, C.; Li, C.H.; Yu, H.C.; Song, X.F.; Zou, G.Y.; Jie, L. Study on ecological restoration in near-shore zone of a eutrophic lake, wuli bay, taihu lake. Ecol. Eng. 2012, 37, 1434-1437. [CrossRef]

32. Yu, D.; Jiang, Y.; Wang, Z.H.; Zheng, C.Y.; Zhu, J.L.; Wang, X.P.; Sheng, Z.H.; Fang, J.Y.; Tang, Z.X.; He, J.S. Methods and protocols for plant community inventory. Biodivers. Sci. 2009, 17, 533-548. 